DOI 10.15290/cnisk.2020.02.09.03

BEATA WALĘCIUK-DEJNEKA

https://orcid.org/0000-0002-6034-5129

Uniwersytet Przyrodniczo-Humanistyczny w Siedlcach

\title{
Portret Marii Szetkiewiczówny w panieńskich listach do matki ${ }^{1}$
}

\section{Streszczenie}

Artykuł jest literaturoznawczym spojrzeniem na prawie zupełnie nieznaną sylwetkę Marii Szetkiewiczówny, żony Henryka Sienkiewicza, i jej korespondencję $z$ matką Wandą Szetkiewiczową. Listy córki do matki ukazuja oczytaną, ambitną i pragnąca różnorodnej nauki młodą niewiastę. Ponadto Maria okazuje się kobietą nowoczesna, samodzielną i niezależną, co w XIX w. należało do rzadkości. Pokazują też matkę jako kobietę spokojna, zrównoważona, kochająca i decyzyjna. Dominujacym tematem korespondencji obu

\footnotetext{
1 Artykuł stanowi kolejna publikację w autorskim projekcie „kobiecego "bycia-wświecie»”. Opublikowane w tym cyklu teksty to m.in.: Beata Walęciuk-Dejneka, „Nowa "ja". Autorskie stwarzanie siebie na podstawie "Pamiętników" Zofii Tołstojowej (wybór)", w: Joanna Posłuszna, Beata Walęciuk-Dejneka (red.), Tożsamość kobiet: silne indywidualności w sztuce, literaturze i religii, (Kraków : Wydawnictwo Aureus, 2014), 49-56; eadem, „Kobieca koncepcja "bycia-w-świecie»: "ja" w rodzinie: $z$ "Pamiętników" Zofii Tołstojowej”, Prace Literaturoznawcze, nr 3, 2015, 197-208; eadem, „Kobiece doświadczanie drogi: "ja“ w podróży. Rozważania na podstawie "Wspomnien" Anny Dostojewskiej”, Prace Literaturoznawcze, nr 4, 2016, 99-113 czy eadem, „W cieniu. Zofii Tołstojowej (1844-1919) i Anny Dostojewskiej (1846-1918) skrywane pisarstwo", Studia z Historii Społeczno-Gospodarczej, t. 16, 2016, 111-121 [online] [dostęp: 19.11.2020]. Dostępny w World Wide Web: http://repozytorium.uni.lodz.pl:8080/xmlui/bitstream/handle/11089/21897/0_7_\%5b 111\%5d-121_Waleciuk-Dejneka.pdf?sequence=1\&isAllowed=y), a także: eadem, „Samodzielna, odważna, nowoczesna: historia Marii Morzyckiej-Obuchowskiej w świetle wybranych fragmentów jej pamiętników", Czasopismo Naukowe Instytutu Studiów Kobiecych, nr 2(3), 2017, 9-22 oraz eadem, „Portret Bibianny Moraczewskiej - literatki nieznanej”, Czasopismo Naukowe Instytutu Studiów Kobiecych, nr 2(5), 2018, 65-78.
} 
pań jest zdrowie, a właściwie jego brak. Celem artykułu jest zatem literaturoznawcza analiza i interpretacja tej korespondencji - Maria jawi się w niej jako kobieta wewnętrznie silna, stanowcza, a przy tym wrażliwa, delikatna i cierpiąca.

Słowa klucze: epistolografia, list-wyznanie, Maria Szetkiewiczówna, XIX wiek, Henryk Sienkiewicz

\title{
MARY SZETKIEWICZÓWNA'S PORTRAIT IN MAIDEN LETTERS TO HER MOTHER
}

\begin{abstract}
The article is a literary perspective on the creative unknown profile of Maria Szetkiewiczówna, wife of Henryk Sienkiewicz, and her letters to mother - Wanda Szetkiewiczowa. The daughter's letters to her mother show a well-read, ambitious and young woman who wants to learn in a variety of ways. In addition, Maria turns out to be a modern, self-reliant and independent woman, which was rare in the nineteenth century.

They also show their mother as a calm, balanced, loving and decision-making woman. The dominating theme of both ladies' correspondence is health, or rather the lack of it.

Keywords: correspondence, letter-confession, Maria Szetkiewiczówna, 19th century, Henryk Sienkiewicz

\section{Panieński list-wyznanie}

O tym, że listy stanowią bogate i wieloaspektowe, przy tym bezcenne źródło informacji lub twórczości, a także dokument biograficzny dla historyka literatury czy innego badacza, nie trzeba nikogo przekonywać. Można $z$ nich zarówno wiele wyczytać na temat osobisty piszącego, jego relacji z rodzina, bliskimi, znajomymi, jak i dowiedzieć się o czasach, w których żył, o kraju, świecie, o wydarzeniach historycznych, społecznych, obyczajowych. Sa również cennym świadectwem epoki oraz ważnych wydarzeń narodowych czy międzynarodowych.

Przypomnijmy za klasyczna już teoria Stefanii Skwarczyńskiej, że list ma obfitą i różnorodną, sięgająca antyku, historię, jest „autonomicznym rodzajem literackim", zaliczony został do literatury stosowanej, a ze względu na podział teoretyczny można wyróżnić: list-mowę,
\end{abstract}


list-pół-dialog, list-rozmowę i list-wyznanie ${ }^{2}$. Na szczególną uwagę zasługuje ten ostatni rodzaj listu, charakterystyczny dla korespondencji, której przyjrzymy się w niniejszym artykule: panieńskim listom Marii Szetkiewiczówny do matki Wandy Szetkiewiczowej. Jak zauważa Skwarczyńska, w liście-wyznaniu odbija się psychika autora, jego emocje, „wnętrze jego duszy”, świat uczuciowy: „... pewien konglomerat danych intelektualnych, uczuciowych i wolitywnych, który miał wyczerpać całe "ja" autora. Celem listu-wyznania jest płynace $z$ lubowania się sobą wypowiedzenie się przed samym sobą, bardziej nawet niż chęć przelania tego lubowania na druga osobę"3.

List-wyznanie bliski jest formie pamiętnika. Oddaje rzeczywistość jak najbardziej wiernie i prosto, a przy tym ujawnia pewna indywidualistyczną wizję podmiotu mówiącego, eksponuje jego osobowość, świadome próby określenia swojego miejsca w życiu, w życiu innych, w relacjach $z$ nimi czy w świecie. Doświadczenia i obserwacje transponowane w pismo - tu: do kobiecego listu - wyłaniaja nie zawsze oczywista i dostrzegana, ale dynamiczna, perspektywę oglądu, autentyczną i podbudowaną emocjami. Chodzi w niej również o „samookreślenie”, odnoszące się, jak wskazuje Brigitte Gautier, do „kobiecej tożsamości, kobiecego życia i kobiecej narracji”" W liście, zauważa też Janusz Maciejewski, autor opowiada o sobie, zwierza się, zadaje pytania, relacjonuje wydarzenia, wyznaje uczucia, przedstawia emocje, określa ich siłę, apeluje o wzajemność, także wyraża poglądy, interpretuje świat ${ }^{5}$. Pojawiające się najczęściej elementy-tematy rzeczywistości epistolarnej to przyjaźń, miłość, małżeństwo. Ale również uwagi na tematy polityczne, narodowe, społeczne, literackie, związane z zainteresowaniami piszącego, jego pasja lub ogólne, stanowiące fragmenty codzienności.

\footnotetext{
2 Stefania Skwarczyńska, Teoria listu, (Białystok : Wydawnictwo Uniwersytetu w Białymstoku, 2006), 32-52. Pisze też o tym Małgorzata Czermińska, vide: Małgorzata Czermińska, „Rola odbiorcy w dzienniku intymnym”, w: Tadeusz Bujnicki, Janusz Sławiński (red.), Problemy odbioru i odbiorcy, (Wrocław : Zakład Narodowy im. Ossolińskich, 1977), 112 .

3 Stefania Skwarczyńska, Teoria listu, 45-46.

4 Brigitte Gautier, „Zaklęcia czarodziejki Vivien, czyli o autobiografii kobiecej”, w: Grażyna Borkowska, Liliana Sikorska (red.), Krytyka feministyczna. Siostra teorii i historii literatury, (Warszawa : Wydawnictwo Instytutu Badań Literackich, 2000), 152.

5 Janusz Maciejewski, „List jako forma literacka”, w: Jolanta Sztachelska, Elżbieta Dabrowicz (red.), Sztuka pisania. O liście polskim w wieku XIX, (Białystok : Wydawnictwo Uniwersytetu w Białymstoku, 2000), 216.
} 
W listach Marii Szetkiewiczówny do matki dominującym tematem na tle wyżej wspomnianych jest zdrowie, a właściwie jego brak. Ciagłe informacje o samopoczuciu, przebytych i nieprzebytych kuracjach, kapielach, stanie fizycznym i psychicznym, bólach i cierpieniach, słabościach, zmęczeniu, ale i chwilowej poprawie, radościach, stanach euforii stanowia motywy przewodnie korespondencji córki $z$ matką. W niniejszym artykule pod ogląd naukowy poddane zostaną listy panieńskie Marii Szetkiewiczówny z okresu: od 14 lipca 1880 r. do 22 stycznia $1881 \mathrm{r}$. ( $z$ dopiskami i komentarzami), pisane przede wszystkim do Wandy Szetkiewiczowej (26 listów), do rodziców Wandy i Kazimierza Szetkiewiczów (4 listy), do ojca Kazimierza (1 list), do siostry (prawdopodobnie) Jadwigi Szetkiewiczówny (1 list) oraz do Henryka Sienkiewicza (1 list). Powyższe listy zostały zebrane, opracowane, opatrzone wstępem i przypisami przez Barbarę Szargot ${ }^{6}$, stanowią też pierwszą część twórczości epistolarnej Marii, na druga składaja się listy mężatki. Celem pracy będzie literaturoznawcza analiza i interpretacja tej korespondencji, ukazującej Marię jako osobę wewnętrznie silna, stanowcza, a przy tym wrażliwa, delikatna, a przede wszystkim schorowana i cierpiąca. To także niewiasta o rozległych horyzontach myślowych, oczytana, wyedukowana, o nowoczesnych poglądach i przekonaniach, własnym zdaniu, bystra i baczna obserwatorka innych, otoczenia czy świata. Postaram się poniżej nakreślić portret kobiety $z$ drugiej połowy XIX w., nie zaniedbując również istoty jej korespondencji $z$ matka, wzajemnych relacji i więzi oraz ustalonych przez epokę stylów i mód.

\section{Oczytana, ambitna, żądna wiedzy}

Maria Szetkiewiczówna to córka Kazimierza Szetkiewicza i Wandy z Mineyków, przyszła żona Henryka Sienkiewicza. Jak podają biografowie pisarza, urodziła się 20 września 1854 r. we wsi Hanuszyszki w Trockiem (obecnie na Litwie), należącej do rodziny Szetkiewiczów, a potem, zgodnie $z$ ukazem, przejętej przez rząd carski. Miała jedną siostrę, Jadwigę, przyszła żonę Edwarda Janczewskiego, rektora i dziekana Uniwersytetu Jagiellońskiego, botanika zajmującego się fizjologią roślin. Ojciec Marii

\footnotetext{
${ }_{6}$ Maria z Szetkiewiczów Sienkiewiczowa, Listy, opracowała, wstępem i przypisami opatrzyła Barbara Szargot, (Piotrków Trybunalski : Naukowe Wydawnictwo Piotrkowskie, 2012), (część pierwsza lisów: listy panieńskie, 37-107).
} 
w latach 1861-1863 był komisarzem do spraw włościańskich, został aresztowany w 1863 roku i wywieziony do Ufy, skąd przenoszono go kolejno do: Belebeju, Kazania, Niżnego Nowogrodu, Moskwy, Riazania, Pskowa. Zimę 1866/1867 Maria wraz z matką i rodziną spędziła u ojca w Riazaniu. W 1868 roku wszyscy przyjechali do Warszawy, ponieważ ojciec otrzymał pozwolenie na powrót do kraju. Sienkiewicza poznała za granica, w czasie pobytu $z$ rodzicami w Wenecji. Ślub ich odbył się w sierpniu 1881 r. (na co wskazuje zachowane zaproszenie). Żona pisarza była ponad cztery lata. Mieli dwoje dzieci, córkę Jadwigę i syna Henryka. Kilka lat stanu panieńskiego i lata małżeństwa Maria ciężko chorowała na gruźlicę, wówczas jeszcze nieuleczalną. Chociaż udawało się łagodzić ostre ataki i powroty dolegliwości ciagłymi niemal wyjazdami do zagranicznych sanatoriów i uzdrowisk, pojawiały się dni i tygodnie pogodne i radosne, to jednak odeszła przedwcześnie. Zmarła 19 października 1885 r. w uzdrowisku Falkenstein, mając zaledwie 31 lat. Pochowana została na Powazkach w Warszawie ${ }^{7}$.

Maria była oczytaną i pragnąca różnorodnej nauki młodą kobieta. Wskazuja na to przywoływane w korespondencji ambitne lektury: Historia cywilizacji w Anglii Henry'ego Thomasa Buckle'a, Geografia porównawcza i Chemia Richtera, dzieło Mendelejewa, Ekonomia polityczna Milla czy publikacja Thomasa Babingtona Macaulaya, o które prosi matkę lub na które się powołuje, a także jej stwierdzenie: „ja od 7-9 wieczorem chcę czytać coś "poważniejszego" albo „teraz przeczytałyśmy La Question d'argent Dumasa". Nie miała więc problemów z pisaniem, o czym świadczy leksyka i erudycja jej poczty, prawdopodobnie $z$ wysławianiem się też nie. Zacytujmy odpowiedni fragment, w liście do siostry pisze: „Poprzedziła mnie tutaj opinia sawantki: C'est une personne qui pousse la science. Tak powiedziała pani Goldstand, a że rzadko jesteśmy w sali, pani Miniewska ... pytała pana S[obotkiewicza], czy i tutaj tak bardzo pracujemy"9.

\footnotetext{
7 Julian Krzyżanowski, Henryka Sienkiewicza żywot $i$ sprawy, (Warszawa : Państwowy Instytut Wydawniczy, 1973), 92-93; Maria z Szetkiewiczów Sienkiewiczowa, Listy, 5-13 (wstęp).

8 Vide listy do matki z 17 września 1880 r., z 10 stycznia 1881 r. oraz z 11 listopada 1880 r. w: Maria z Szetkiewiczów Sienkiewiczowa, Listy, 48, 100, 73, 101; w przypadku Macaulaya prawdopodobnie chodzi o Dzieje Anglii, o które prosi w wersji angielskiej.

9 Sawantka, $z$ fr. savante, to kobieta wykształcona, chętnie popisująca się erudycja; zdanie francuskie oznacza: to osoba pełna wiedzy (nauki), dosłownie: $z$ której wyrasta nauka,
} 
Szetkiewiczówna poza tym była osobą żądną wiedzy i wykształcenia, o urozmaiconych zainteresowaniach. We wspomnieniach Marii Korniłowiczówny, wnuczki, czytamy:

odrzucała jedna po drugiej wszystkie partie i chciała studiować. Uczyła się chemii. Już nawet rodzice na serio rozważali czy nie wypadnie przenieść się $z$ całą rodziną do Zurychu, gdzie był wówczas jedyny w Europie uniwersytet, który przyjmował kobiety. W Warszawie nie szczędzili (...) na najlepszych prywatnych profesorów. O wysłaniu panny za granicę samej oczywiście nie mogło być mowy, mimo że od dawna była pełnoletnia ${ }^{10}$.

W biografii Sienkiewicza Józef Szczublewski potwierdza powyższe uwagi: „drobna, krucha, jasnowłosa emancypantka, wybiera się za granicę, ażeby studiować chemię"11.

$Z$ listów wyłania się portret pewnej indywidualności, kobiety niemieszczącej się w żadnych schematach, stereotypach tamtych czasów, niewiasty oryginalnej, wyrastającej ponad przeciętna, potrafiącej urzec humorem, wdziękiem, kobiecościa, ale też stanowczej i zdecydowanej. Tak pisała do matki o Sienkiewiczu, starającym się o jej rękę:

Mamy list okropny. Nie mówię, że za surowy, że niesprawiedliwy, ale nic niewyjaśniający. Zdaje się, że wymierzony na to, żeby rozdrażnić i wyprowadzić $z$ siebie, a nie wskazać drogi działania. ... Matka w tym położeniu może wyraźnie sformułować wszystkie zarzuty czarno na białym, ma prawo wyrazić powatpiewanie ... powinna jasno postawić żądania ... Można Go wezwać, oddać mu list mój i powiedzieć, co Mama uważa za potrzebne ${ }^{12}$.

Nawet wnuczka po latach wspomina, że babci [tj. Marii] udało się „przełamać w mężczyźnie [tj. mężu Henryku Sienkiewiczu] stereotyp poczciwej kobietki”13, zaś jemu [tj. Sienkiewiczowi], „takiej trzeba było, mocnej duchowo, umiejącej wymagać, a pełnej humoru i optymizmu,

która rośnie nauka, cyt. za: Maria z Szetkiewiczów Sienkiewiczowa, Listy, 40, przypis 6, 7; list z 14 lipca 1880, 40.

10 Maria Korniłowiczówna, Onegdaj: opowieść o Henryku Sienkiewiczu i ludziach mu bliskich, (Szczecin : Glob, 1985), 70.

11 Józef Szczublewski, Sienkiewicz. Żywot pisarza, (Warszawa : W.A.B., 2006), 89.

12 Maria z Szetkiewiczów Sienkiewiczowa, Listy, 53-54 (list z 24 września 1880).

13 Maria Korniłowiczówna, Onegdaj: opowieść o Henryku Sienkiewiczu, 122. 
mądrze kochającej żony, która zarówno człowiekowi, jak i artyście potrafiła wytyczyć kierunek i która musiał uwielbiać"14.

Pozornie, jak zaznacza Barbara Szargot, mamy do czynienia z pokorna córka „patriarchalnych rodziców”, która decyzję w sprawie Sienkiewicza oddaje $\mathrm{w}$ ich ręce. Jednak to ona proponuje matce schemat postępowania, przypomnijmy: „Matka ... może wyraźnie sformułować wszystkie zarzuty czarno na białym, ma prawo wyrazić powątpiewanie ... Można Go wezwać, oddać mu list mój i powiedzieć, co Mama uważa za potrzebne". Wyraźnie więc zauważalna jest niezależność Marii, samodzielność, pewna kategoryczność, postawienie pewnych warunków, przyjęcie strategii działania. Barbara Szargot w odniesieniu do zaistniałej sytuacji pisze: „Możemy zaobserwować wahanie matki, jej niezdolność do sformułowania zarzutów i determinację córki, która chce wymusić, by właśnie matka przedstawiła konkurentowi zarzuty i żądania ... Nie sposób nie zauważyć, że "Mańcia" posuwa się do emocjonalnego szantażu - zaczyna opowieścią o rozdrażnieniu i przykrości, a kończy powtórnie pisząc o zdenerwowaniu i bólach, które pod jego wpływem się pojawiły"15.

Henryk Sienkiewicz w listach do Stanisława Witkiewicza, przyjaciela, zwierzał się na temat myśli i uczuć do Marii, z końcem stycznia 1881 r. zanotował: „Oddałbym nie wiem co, by choć przez parę dni widzieć pannę Marię, która jest najdroższa dla mnie w świecie istota i jedyna kobieta, która pragnąbym nazwać żona, ale nie wiem, czy matka zgodzi się na to”. A nieco dalej: „Gdyby mnie znała bliżej ... byłaby niezawodnie o los panny Marii ze mna spokojniejsza. Być może, że dziś bliższa jest oddania mi jej, niż była, ale nie wszystkie lody zostały jeszcze złamane ... Dziś jest lepiej. Bywam przynajmniej u rodziców i ci przypatruja mi się własnymi oczyma"16. Po rocznym staraniu się o rękę Marii Sienkiewicz został narzeczonym.

\section{Zdrowie, a właściwie jego brak}

Dominujacym tematem korespondencji $z$ matka, o czym wspominaliśmy wyżej, jest zdrowie, a właściwie jego brak. Niemalże w każdym liście pojawiaja się informacje córki o samopoczuciu, o kuracjach,

\footnotetext{
14 Ibidem, 76.

15 Maria z Szetkiewiczów Sienkiewiczowa, Listy, 17.

16 Julian Krzyżanowski, Henryka Sienkiewicza żywot $i$ sprawy, 88.
} 
o braku apetytu albo o nadmiernym łakomstwie. Zacytujmy odpowiednie fragmenty:

... biorę sumiennie kurację i szanuję się bardzo. W zeszłym tygodniu miałam katar i lekką niedyspozycję żołądka, ale teraz już mi zupełnie dobrze. Jednakże staram się chodzić jak najmniej i nie oziębiać się ${ }^{17}$,

... szwy są bardzo znaczne w płucach, że mogą spowodować powtórzenie się zapalenia czy też przyczynić się do rozwinięcia cierpienia płucnego, co przy tak wattym jak mój organizmie, może być bardzo groźne. Zalecił [lekarz] hartowanie się i chodzenie po górach, siedzenie ciagłe na powietrzu, a rano nacieranie zimna woda (słona). Przy tym jeść, spać i pić co najwięcej ... Rano będę brać natarcia (jak nic w płucach czuć nie będę), potem kakao, o 12-tej mięsne śniadanie, o 5-tej obiad, po którym już się nie wychodzi z domu ${ }^{18}$.

Ciagłe wiadomości o zdrowiu dowodza, że gruźlica musiała być już tak zaawansowana, że wszelkie dolegliwości, osłabienie, wyczerpanie, chroniczne zmęczenie, brak sił do działania, nieodpowiedni wygląd towarzyszyły Marii niemalże codziennie: „Bardzo się podobałam Kolonowskiemu: piękna, rozumna i oryginalna, tylko strasznie mizerna. Cóż dopiero, żeby dawniej widział, kiedy naprawdę chuda byłam!"19. Albo: „... moja choroba kiszek czy nerwów wcale nie jest uleczona. Od 6 czy 7 dni znowu bardzo mało mogę chodzić, czuję natężenie muskułów, osłabienie miejscowe, a $z$ tego i ogólne. $Z$ każdej przechadzki ... powracam tak zmęczona, że pół godziny posiedzieć nieruchomie muszę"20.

Maria narzeka również na życie poza domem, na prowincji, $z$ dala od rodziny, od matki, ojca, martwi się o nich, bardzo tęskni, co otwarcie wyraża w korespondencji: „Napiszcie drogie dzieci ... Dobrze mi tu, ale chciałoby się być już z Wami”"21, w innym miejscu: „Żeby Mama wiedziała, jak ja chcę powracać. Ze wszystkich względów chcę wracać”22 albo „Chce mi się już być z Wami, objać tę Mateczkę mocno, mocno pokochać,

17 Maria z Szetkiewiczów Sienkiewiczowa, Listy, 56 (list do rodziców, z 29 września 1880 r.).

18 Ibidem, 66-67 (list do matki z 3 listopada 1880 r.).

19 Ibidem, 49 (list do matki z 17 września 1880 r.).

20 Ibidem, 93 (list do matki z 21 grudnia 1880 r.).

21 Ibidem, 41 (list do matki z 16 lipca 1880 r.).

22 Ibidem, 76 (list do matki z 11 listopada 1880 r.). 
a Ojcu położyć łapki na skroniach, a głowę złożyć na głowie. Kontent będziesz, Malutki"23.

Na uwage zasługuja zwroty Marii do matki, ojca czy do rodziców razem, świadczące o wielkiej miłości, oddaniu, głębokim uczuciu dziecięcia, chociaż to właśnie rodziców nazywa „drogie dzieci”. Listy są również pełne egzaltacji, zapewnień o miłości, niestrudzonej pamięci, cechuja je szczerość, prawdziwość, wzniosły styl, osobistość, wynurzenia intymne. Ale znajdują się też w nich typowe ploteczki, ciekawostki na temat wspólnych znajomych, rodziny, rozrywek, którym „oddaje się” Maria, wyjść do kawiarni, na spacery, relaksu. Sporo miejsca w korespondencji zajmuja również tematy z życia codziennego w sanatoriach i uzdrowiskach pokazujące Marię jako rozwinięta intelektualnie, towarzyską kobietę, mądra i zorientowana w sprawach $z$ życia obyczajowego, społecznego czy politycznego. Przywołajmy odpowiednie fragmenty: „Nie masz pojęcia jakie rozrzucone życie prowadzimy tutaj. Ani na pacierz czasu nie ma i myśli trudno zebrać ... spotykam zaraz różne baby znajome i nieznajome: Lolę, ładne panny Goldstand, inne pannice, a Kanta, a Domaniewskiego ..., itd., itd.” ${ }^{24}$ czy: „Przyjechał do hotelu gość znamienity - żona byłego ministra Becka, Polka $z$ urodzenia. Siedzi naprzeciw u stołu i ciagle nas zaczepia, przemawiając w różnych językach, zaprosiła nas do siebie i obiecałyśmy jej swoją bytność. Jest to wielkiej brzydoty kobieta, bardzo już schorowana i stara, ale musiała kiedyś lubić życie"25. I jeszcze jeden cytat: „Przybyła mi nowa znajomość. P[aństwo] Klobas[s]a z Galicji ... spotkaliśmy ich na ulicy, zaprezentowano mnie, a wczoraj była u nas ta Pani i pytała o "panny obie». Pójdę zatem do nich. Sama pani wielka elegantka, dystyngowana i piękna"26.

W korespondencji uwidaczniają się także smutki, nostalgia, żal, które wynikaja głównie $z$ braku zdrowia. W liście z 3 listopada 1880 r. Maria narzeka na samotność, zwierza się matce $z$ tęsknoty: „Mieszkamy [z Maria Sobotkiewiczówna] na Obermais tak daleko od Meranu, że znowu samotność absolutna. Te wieczory długie bardzo mnie przerażaja, ale będę rozumna i dlatego, że nudno, wyrywać się nie będę. Tak chce się czasami wziąć tę Mateczkę za głowę i mocno pokochać, albo Ojcu wir

\footnotetext{
${ }_{23}$ Ibidem, 58 (list do rodziców z 29 września 1880 r.).

24 Ibidem, 39 (list do siostry z 14 lipca 1880 r.).

25 Ibidem, 94 (list do matki $z 21$ grudnia 1880 r.).

${ }^{26}$ Ibidem, 96 (list do matki z 24 grudnia 1880 r.).
} 
rozrzucić, przeszkodzić les $R a$ robić i oberwać brzydkie słowo. Ale człowiek rozumny jest i nie pozwala sobie chcieć" ${ }^{27}$.

\section{Czy kontakt listowny z XIX wieku może być dziś ciekawy?}

Korespondencja córki do matki pozwala na poznanie obu pań, doskonale uzupełnia fakty $z$ życiorysu. Zastanawiać może jedynie, o czym pisała młoda kobieta (panna, żona) do matki w drugiej połowie XIX w., czy ich kontakt listowny może być dziś ciekawy. Oprócz poruszonych powyżej spraw i tematów w dialogu $z$ matką pojawiają się jeszcze kwestie finansowe (opłaty za pobyt Marii w uzdrowiskach) oraz modowe. W liście do Wandy Szetkiewiczowej z 17 grudnia 1880 r. czytamy, jak Maria martwi się o wydatki rodziców, które są przeznaczane na jej utrzymanie: „O, ja Was, drogie dzieci, mocno kosztuję, co przy teraźniejszej drożyźnie i niepokoju o Lipków smutnymi robi ojcowskie finanse. Ale niech się tylko uda Lipków rozprzedać i zarobić, to się pokryje moją małą osóbkę wraz z wydatkami”28. Natomiast w liście do ojca, Kazimierza Szetkiewicza, z 9 grudnia 1880 r. pisze: „Całuję Was, moi mili, i płaczę, że Was drogo kosztuję"29. I dołącza zestawienie wydatków - rachunek sporządzony przez nia, w którym zaznacza: wydatki na kurację, na podróże $\mathrm{i}$ inne rzeczy, takie jak np. praczka, mieszkanie, ubiory, przesyłki itp. oraz kwotę, jaka dostała od rodziców ${ }^{30}$.

O modzie i strojach „rozmawiaja” obie kobiety dość często, dla przykładu:

Mama mi każe dobrze być ubraną. Trochę trudno, trzeba by kupić nowe okrycie zamiast nietoperza [rodzaj okrycia $z$ szerokimi rękawami], kapelusz, suknię itd. Suknia czarna jest niemożliwa, brazowa trzyma się, ta $\mathrm{z}$ aksamitem zupełnie dobra, ale dziwnie niewygodna do chodzenia. Pojawily się tu w sklepie staniki trykotowe po 9 g[uldenów], różnych kolorów, dorabia się spódniczka i suknia gotowa. Czy Mam radzi? Kazać robić suknię - bardzo drogo, gotowe źle leżą i szpetne,

27 Ibidem, 67-68.

28 Ibidem, 91.

29 Ibidem, 83.

30 Ibidem, 84-88. 
więc to będzie się najpraktyczniej. Kapelusz kupię miękki, ale teraz taki za goracy ${ }^{31}$.

Prywatne listy sa szczególnym tekstem, zwłaszcza te, które stanowią zbiór regularnej korespondencji dwojga bliskich sobie osób. Zawierają różnorodne informacje związane $z$ codziennymi problemami życia i odzwierciedlaja wzajemny ich stosunek. Pisanie miało dla Marii niebagatelny sens, było ważnym ogniwem wypełniającym porządek dnia, a więc obok potrzeb utylitarnych wyzwalało pewne psychiczne pragnienia i stanowiło element terapii i jej własnej filozofii życiowej. Schorowana i cierpiąca przelewała na papier smutek i męki, a pisanie zaspokajało potrzebę kontaktów $z$ bliskimi, chęć wypowiedzi, wynurzenia się przed matka, zwierzenia się ze swych bólów, żałości, sądów czy opinii.

Listy modeluja portret kobiety, pozwalają dostrzec jej wady i zalety. Te osobiste i bardzo intymne wyznania ukazują Marię w najdelikatniejszych odcieniach: drobne i wielkie namiętności, sympatie i antypatie, uczucia i emocje, najgłębsze i najskrytsze zwierzenia. Prezentują też matkę jako kobietę spokojna, zrównoważona, kochająca i decyzyjną. Korespondencja Marii $z$ Szetkiewiczów $z$ matką jest próbą przybliżenia obrazu obu niewiast, o których Stefania Skwarczyńska pisała: „Korespondencja ... stanowi ... twór samoistny, ograniczony, o własnym obliczu ... całość korespondencyjna ujawnia w pełni dwoistą naturę epistolografii - naturę życiową i pisarsko-literacka. Zarysowuje się ona ... w słowach, w niedomówieniach, przemilczeniach i zamilknięciach, nawet w przerwach toku korespondencyjnego, także o walorach semantycznych"32.

Takie czytanie listów Marii pozwala na lekturę otwarta, na ukazanie tego, co w tekście obecne i nieobecne, jawne i ukryte, uwalnia od sądów, stwarza możliwości interpretacyjne, a samą pannę pokazuje jako niezależną, dobrze wychowaną, nowoczesną i samodzielną.

31 Ibidem, 77 (list do matki z 11 listopada 1880 r.).

32 Stefania Skwarczyńska, „Wokół teorii listu (Paradoksy)”, w: eadem, Pomiędzy historia a teoria literatury, (Warszawa : PAX, 1975), 184. 


\section{Bibliografia}

\section{Źródła}

Maria z Szetkiewiczów Sienkiewiczowa. Listy, opracowała, wstępem i przypisami opatrzyła Barbara Szargot, (Piotrków Trybunalski : Naukowe Wydawnictwo Piotrkowskie, 2012), (część pierwsza lisów: listy panieńskie, 37-107).

\section{Opracowania}

Czermińska, Małgorzata. „Rola odbiorcy w dzienniku intymnym”, w: Tadeusz Bujnicki, Janusz Sławiński (red.), Problemy odbioru i odbiorcy: studia, (Wrocław : Zakład Narodowy im. Ossolińskich, 1977), 105-122.

Gautier, Brigitte. „Zaklęcia czarodziejki Vivien, czyli o autobiografii kobiecej”, w: Grażyna Borkowska, Liliana Sikorska (red.), Krytyka feministyczna. Siostra teorii $i$ historii literatury, (Warszawa : Wydawnictwo IBL, 2000), 152-158.

Korniłowiczówna, Maria. Onegdaj: opowieść o Henryku Sienkiewiczu i ludziach mu bliskich, (Szczecin : Glob, 1985).

Krzyżanowski, Julian. Henryka Sienkiewicza żywot $i$ sprawy, (Warszawa : PIW, 1973).

Maciejewski, Janusz. „List jako forma literacka”, w: Jolanta Sztachelska, Elżbieta Dabrowicz (red.), Sztuka pisania. O liście polskim w wieku XIX, (Białystok : Wydawnictwo Uniwersytetu w Białymstoku, 2000), 211-218. Skwarczyńska, Stefania. Teoria listu, (Białystok : Wydawnictwo Uniwersytetu w Białymstoku, 2006).

Skwarczyńska, Stefania. „Wokół teorii listu (Paradoksy)”, w: Stefania Skwarczyńska, Pomiędzy historia a teoria literatury, (Warszawa : PAX, 1975), 178-186.

Szczublewski, Józef. Sienkiewicz. Żywot pisarza, (Warszawa : W.A.B., 2006). 